\title{
Auditing the Auditors: An Indian Perspective
}

\author{
Anil Kumar \\ Associate Professor, Shri Ram College of Commerce \\ University of Delhi, Delhi-110007, India
}

Tel: 91-9810-857-745_E-mail: anilkumar@srcc.edu

Received: November 15, 2018 Accepted: December 4, 2018 Published: December 6, 2018

doi:10.5296/ijafr.v8i4.13920

URL: https://doi.org/10.5296/ijafr.v8i4.13920

\begin{abstract}
Setting up of National Financial Reporting Authority (NFRA) in India as an independent regulator to audit the auditors has renewed a debate on 'peer review' and 'independent review'. While the global practice is that of an independent oversight over the auditors, the professional body of auditors in India- Institute of Chartered Accountants of India (ICAI) is opposed to the move of the government to appoint a regulator over auditors. This paper examines the perception of auditors and other stakeholders in India on the mechanism of auditing the auditors. The study finds that all stakeholders including practicing public accountants believe that the present state of auditing is not satisfactory in India. The difference in perception is on the setting up of the independent authority (NFRA) to audit the auditors. While the chartered accountants in India believe that self-regulation over the auditors through the existing mechanism may be made more effective, the other stakeholders overwhelmingly support the quasi-regulatory body for independent review of audit service.
\end{abstract}

Keywords: Auditors, Peer review, Financial regulation

JEL Classification: M42, G180

\section{Introduction}

Reviewing the audits is a well-established practice to assure the quality of audit services. In 1988, the American Institute of Certified Public Accountants (AICPA) made periodic quality peer review of public accounting firms compulsory (Alam et al., 2000). Erosion of the credibility of auditors following the collapse of big corporations in the US- Enron and WorldCom at the turn of this century mounted pressure on the federal government to regulate the auditors more stringently. Public Company Accounting Oversight Board (PCAOB) was established in 2002 by Sarbanes-Oxley Act (SOX) to review the audits of public companies. 


\section{Mll Macrothink}

International Journal of Accounting and Financial Reporting

ISSN 2162-3082

2018, Vol. 8, No. 4

The PCAOB with a mandate to set up audit standards and conduct inspections and disciplinary proceedings against the errant auditors unleashed a regime of independent review of audit firms which were self-regulated until then. PCAOB, although a non-profit body is under the supervision of Securities and Exchange Commission (SEC) which approves the rules, standards and budget of the Board and also appoints five members and chairman of the Board. The funding of PCAOB comes largely from public companies and broker-dealers through the support fees levied on them. PCAOB has been quite effective in auditing the public accountants in the US through issuing numerous auditing standards; rules for the auditors; regular inspections of registered public accounting firms to assess compliance with the regulations; and penalising the errant auditors.

Financial Reporting Council (FRC) is the independent regulator in the UK to promote high quality corporate governance and reporting. FRC sets codes and standards for governance, accounting and auditing; reviews reports of public interest entities; and has the power to investigate misconduct by professional accountants. While FRC has direct statutory powers in relation to audit regulations, some of the functions of FRC have no statutory backing but have been derived from widespread support of the professional bodies in the UK. FRC is funded by the audit profession who are required to contribute under the provisions of the Companies Act 2006.

Similarly in Australia, Financial Reporting Council (FRC) set up under the Australian Securities and Investments Commission Act 2000 oversees the effectiveness of the financial reporting framework and provides strategic advice in relation to the quality of audits conducted by the auditors in Australia.

\subsection{Audit Review Mechanism in India}

For nearly 16 years, auditors in India are only self-regulated under peer review. The professional body of accountants in India - Institute of Chartered Accountants of India (ICAI) has established Peer Review Board and Quality Review Board to conduct limited reviews of audit services.

Peer Review Board was established in year 2002 by ICAI to ensure that in carrying out the assurance service assignments applicable technical, professional and ethical standards are followed. The objective being educative to enhance quality of professional work and transparency in audit standards, peer review has no connection with any disciplinary or any other regulatory mechanism. While Peer Review Programme in the US by the SEC Practice Section (SECPS) of AICPA had been quite effective as during the period of 20 years from 1977 to 1997, SECPS conducted 4,021 peer reviews and 769 corrective actions were imposed by the Peer Review Committee (Alam et al., 2000), the Peer Review Board in India has a limited significance only. Its domain being limited to organising training programmes imparting training to the reviewers and issuing Peer Review Certificates to firms reviewed.

Quality Review Board (QRB) seemingly is more powerful peer-review body in India as it consists of half of the members nominated by the government and others by the ICAI. The first Quality Review Board was constituted in 2007 and then in 2011, 2012, 2014, 2015 and 2016. 


\section{MInstitute ${ }_{\text {Mnk }}^{\text {Macrothink }}$}

International Journal of Accounting and Financial Reporting

ISSN 2162-3082

2018, Vol. 8, No. 4

During the period 2012-15, the Board could only review 216 statutory audit assignments and in 74 cases advisories were issued to the audit firms for improvement in their services (Quality Review Board, 2015). QRB, however has never been an effective body as it does not have disciplinary or investigation power over the auditors.

In the midst of intense debate in India to regulate the public accountants in the aftermath of the Punjab National Bank heist of more than \$ 2 billion, the Government of India established National Financial Reporting Authority (NFRA), an independent review body over the auditors and auditing firms with a view to improve the audit quality while retaining self-regulation mechanism by the professional body of auditors. As per section 132(2) of the Indian Companies Act, 2013, the National Financial Reporting Authority (NFRA) shall make recommendations to the government on formulation of accounting and auditing policies and standards. Most importantly NFRA will oversee the quality of service of the professions associated with ensuring compliance with accounting and auditing standards, and suggest measures for improvement in quality of service. NFRA has the twin powers of investigation and judicial powers of a civil court of summoning including imposing penalty and debarring the public accountant or the firm from engaging in practice as chartered accountant.

NFRA is to consist of government appointee chairperson, three full-time, and nine part-time members with a term of three-years each. To make NFRA a wide participating body, it will have representation from different bodies and regulators in the field of accountancy, auditing, law and capital market through their nominees as part time members. The functions of NFRA include the standard setting; monitoring, compliance, review and overseeing quality of service; and enforcement. NFRA is given a mandate to undertake investigation or conduct quality review of audit of following class of companies:

- $\quad$ Listed Companies

- Unlisted companies with net worth equal or more than Indian Rupees (INR) 500 crores or paid up capital equal or more than INR 500 crores or annual turnover equal or more than INR 1000 crores as on 31st March of immediately preceding financial year; or

- Companies having securities listed outside India

The inherent regulatory role of ICAI shall continue in respect of its members in general and specifically with respect to audits of private companies and public unlisted companies below the threshold limit. Quality Review Board (QRB) will also continue to review the audits of private limited companies and public unlisted companies below prescribed threshold.

\subsection{Objectives of the Study}

The objective of this study is to provide empirical evidence on perceptions of oversight over auditors through peer review or independent review body. The research questions which the study addresses are:

(1) What is the Peer Review mechanism over auditors in India and what is the perception of different groups on its effectiveness? 
(2) To which extent do various constituent groups agree with each other concerning the effectiveness of Peer Review mechanism?

(3) What is the perception of auditors on need and effectiveness of NFRA to enhance audit quality?

(4) To which extent do various constituent groups agree with each other concerning the need of NFRA to enhance audit quality?

\section{Literature Review}

Since it is only recently that an independent regulatory body is constituted in India to oversee the auditors, there are no Indian perceptual studies on independent review and peer review of audit services. However, there are a few US based studies which have examined the effectiveness of peer review and independent review mechanisms. The study of Alam et al (2000) examined the perception of audit firms, audit clients, financial analysts, and bankers to evaluate the effectiveness of the peer review programme of AICPA (SECPS section of AICPA). The study reported the perception of all the four constituent groups on the primary goal of the peer review programme as 'improving audit practices' and no significant differences in the perception of groups on the primary goal of peer review programme. The results showed that the peer review mechanism was perceived inadequate for reducing audit failures and detecting audit fraud in financial statements. Ehlen and Welker (1996) studied the perception of fairness of procedures adopted by AICPA in its peer review programme.

The Sarbanes-Oxley Act, 2002 introduced reforms in the US to enhance audit quality and established PCAOB which replaced self-regulation. A number of research studies investigated 'audit quality' before and after SOX. Hilary and Lennox (2005) examined the credibility of peer review programme in the US and contended that notwithstanding shortcomings of peer-review, clients perceive the review reports as being informative signals of audit firm quality. They showed that firms receiving clean peer-review opinions gained clients in the subsequent year and vice versa for unfavourable reports. Russell and Armitage (2006) identified several loopholes within the peer review system through a questionnaire. The studies of DeFond (2010) and Farrell and Shabad (2005) examined in particular PCAOB inspections and reported that inspectors seemingly lacked auditing expertise and were under pressure to identify problems. These studies could not provide evidence whether the inspections improve audit quality. Daugherty and Tervo (2010) found on the basis of responses from 146 accountants of small registered public accounting firms that the inspections improve audit quality for small auditors. The study suggested that smaller CPA firms perceive the initial PCAOB inspections to impact their practice negatively while medium and larger firms reported positive consequences of inspections by PCAOB. This is corroborated by the study of Gramling et al (2011) which concluded that PCAOB inspections have a remedial effect on small auditors. The findings of the study by DeFond and Lennox (2011) pointed out that the threat of PCAOB inspections for small firms compelled nearly half of all such firms to quit the audit services. There is, however, limited evidence that PCAOB inspections improve audit quality for large auditors. 


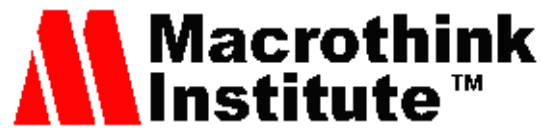

International Journal of Accounting and Financial Reporting

Ragothaman (2012) in her study compared the peer reviews and inspections by PCAOB inspections and concluded independent inspections as tougher and stringent. Houston and Stefaniak (2013) analysed the perception of partners from large and annually inspected audit firms. They reported that a majority of partners believed that PCAOB inspectors compared to Internal Quality Reviews had an inferior knowledge about the audit methodologies of the firms. Robertson and Houston (2010), however, taking a sample of 142 MBA students as a proxy for non-professional investors reported that, under certain conditions, PCAOB reports signal the credibility of audit opinions. A paper by Gipper et al. (2015) examined the investors' assessment of reporting credibility as a consequence of audit inspections by PCAOB. It found that audit oversight by an independent regulator increase the credibility of financial reporting.

Thus, prior literature on auditing the auditors, which is primarily US based indicate a positive effect of PCAOB inspections on audit quality, however the evidences are not conclusive to arrive at a definite conclusion.

\section{Sample and Data Collection}

Data for this study are collected from subjects representing four broad groups through a self-administered questionnaire that was mailed to prospective respondents. The completed questionnaires were pretested to ensure completeness. To avoid bias in sample selection, random mails were sent to different groups of practicing auditors, accountants, chartered accountancy (CA) students, academicians engaged in teaching \& research in accounting and allied fields; other stakeholders from varied fields-bureaucrats, advocates, bankers, corporate managers, owners of SMEs and shareholders of public companies. The segregation in groups was made because it seemed likely that the perception of the groups would differ significantly. The repeated mails to 3455 respondents yielded 198 usable responses, representing 5.73\% overall response rate. The study was conducted from March 2018 to October 2018, a period when Government of India announced setting-up of NFRA, the rules were finalised and the body became operative with the appointment of the chairperson of NFRA.

\subsection{Research Methodology}

Exploratory factor analysis using Principal Component Analysis (PCA) with Varimax rotation was conducted to identify the underlying factors that were influencing the responses of various groups in the study. The analysis extracted three principal factors underlying the perception of respondents. In addition, Chi-square test was conducted on the responses of another set of questions which were administered to the same four groups on perceptions of peer review and independent review body to ascertain whether the opinions of groups on different questions of the questionnaire were independent of the group to which it belonged.

\section{Results and Analysis}

\subsection{Factor Analysis}

The data was tested for sampling adequacy using KMO and found to be adequate $(\mathrm{KMO}=0.762)$. Bartlett's test was found to be significant ruling out any possibility of 
correlation matrix being an identity matrix. Table 1 shows the result of the test. The tests suggest sufficiency and suitability of data for factor analysis.

Table 1. KMO and Bartlett's test

\begin{tabular}{lll}
\hline Kaiser-Meyer-Olkin Measure of Sampling Adequacy. & .762 \\
\hline \multirow{3}{*}{ Bartlett's Test of Sphericity } & Approx. Chi-Square & 541.477 \\
& Df & 45 \\
& Sig. & .000 \\
\hline
\end{tabular}

The factors were extracted using PCA and have eigenvalues more than 1 rotating orthogonally using Varimax rotation. All the variables in the study have communalities greater than 0.5 with the extracted factors except two variables. However, the communalities of these two variables were very close to 0.5 , the benchmark score, and hence were used in the further analysis. The communalities are reported in Table 2 .

Table 2. Communalities

\section{Initial Extraction}

Do you believe there is any need of further review of auditing in India?1.000

Do you think that the current self-regulation by PRB or QRB over auditors is effective?

Do you believe that self-regulation over auditors can be made more effective by strengthening the existing PRB or QRB setup?

Do you think there is a need of greater independent oversight over auditor/auditing firm?

Do you think that auditors are responsible for lapses/window-dressing/frauds in financial statements of companies 1.000 under audit?

Do you think NFRA will be able to exercise independent oversight over the auditors?

Do you think that NFRA will be able to ensure compliance of ${ }_{1.000}$ accounting and auditing standards?

Do you think the constitution of NFRA is a good step by the 1.000 Government?

Do you think NFRA will be able to investigate audit firms?

$$
1.000 \quad .636
$$

Do you think NFRA will emerge as a professional body to guide formulation of accounting, auditing policies/standards and prevention 1.000 of accounting frauds? 


\section{MlMacrothink}

International Journal of Accounting and Financial Reporting

ISSN 2162-3082

2018, Vol. 8, No. 4

Extraction Method: Principal Component Analysis.

Factor analysis extracted three factors (Table 3). However, when tested for internal consistency using Cronbach's Alpha only first factor had a score of 0.801 which is higher than the bench mark of 0.7, and other two factors had very low Cronbach's Alpha (both values were less than 0.3 ), therefore, only the first factors was considered for further analysis.

The factor 'dissatisfaction from the present state of auditing in India' explained approximately $35 \%$ of the variations in the responses. All three factors together explained approximately $60 \%$ variation (Table 4). One variable was strongly crossing over two factors. However, when this variable was dropped from the study even then the results didn't improve much and Cronbach's Alpha still remained less than 0.3. Therefore, it was decided to proceed with the previously obtained results. The predominant first factor on the expected lines was that the present state of auditing is not satisfactory in India, a fact which all the respondents including chartered accountants who are practicing as an individual or as a partner in audit firms strongly believe. This is what was also reported by Alam et al (2000) wherein all the groups in the study felt the need of 'improving audit quality'.

Table 3. Rotated component matrix ${ }^{a}$

Component

$\begin{array}{lll}1 & 2 & 3\end{array}$

Do you think the constitution of NFRA is a good step by the

Government?

.850

Do you think NFRA will be able to investigate audit firms?

.779

Do you think that NFRA will be able to ensure compliance of ${ }^{749}$ accounting and auditing standards?

Do you think there is a need of greater independent oversight over auditor/auditing firm?

Do you think that auditors are responsible for

lapses/window-dressing/frauds in financial statements of companies.621

under audit?

Do you believe there is any need of further review of auditing in India?.556 $\quad-.469$

Do you think NFRA will emerge as a professional body to guide

formulation of accounting, auditing policies/standards and prevention.525

of accounting frauds?

Do you think that the current self-regulation by PRB or QRB over auditors is effective?

Do you believe that self-regulation over auditors can be made more effective by strengthening the existing PRB or QRB setup?

Do you think NFRA will be able to exercise independent oversight over the auditors? 
Extraction Method: Principal Component Analysis.

Rotation Method: Varimax with Kaiser Normalisation

${ }^{a}$ Rotation converged in 5 iterations.

However, public accountants believe that self-regulation over the auditors through the existing Peer Review Board or Quality Review Board may be made more effective as is being done over the years by the ICAI. The academicians engaged in teaching \& research of accounting and allied fields and others representing general public do not agree with this state of affairs. The general perception of the people that auditors are responsible for lapses/window-dressing/frauds in financial statements of companies under audit is reflected by the results of the study. The indictment of the auditors in the recent cases of accounting frauds, noteworthy of them being PNB heist, diversion of funds by Amrapali group of companies, crisis in the debt laden IL\&FS have most likely shaped the perception of the people which most chartered accountants do not agree with.

Table 4. Total variance explained

\begin{tabular}{|c|c|c|c|c|c|c|c|c|c|}
\hline \multicolumn{4}{|c|}{$\begin{array}{l}\text { ComponInitial Eigenvalues } \\
\text { ent }\end{array}$} & \multicolumn{3}{|c|}{$\begin{array}{l}\text { Extraction Sums } \\
\text { Squared Loadings }\end{array}$} & \multicolumn{3}{|c|}{$\begin{array}{l}\text { ofRotation Sums of Squared } \\
\text { Loadings }\end{array}$} \\
\hline & Total & $\%$ & ofCumulat & i Total & $\% \quad$ & ofCumula & ti Total & $\%$ & ofCumulati \\
\hline & & Varianc & ce ve $\%$ & & Variance & e ve $\%$ & & Variance & ve $\%$ \\
\hline 1 & 3.498 & 34.982 & 34.982 & 3.498 & 34.982 & 34.982 & 3.476 & 34.760 & 34.760 \\
\hline 2 & 1.466 & 14.661 & 49.643 & 1.466 & 14.661 & 49.643 & 1.464 & 14.643 & 49.403 \\
\hline 3 & 1.091 & 10.907 & 60.550 & 1.091 & 10.907 & 60.550 & 1.115 & 11.146 & 60.550 \\
\hline 4 & .872 & 8.724 & 69.274 & & & & & & \\
\hline 5 & .737 & 7.371 & 76.644 & & & & & & \\
\hline 6 & .696 & 6.964 & 83.609 & & & & & & \\
\hline 7 & .547 & 5.467 & 89.075 & & & & & & \\
\hline 8 & .459 & 4.587 & 93.662 & & & & & & \\
\hline 9 & .383 & 3.831 & 97.493 & & & & & & \\
\hline 10 & .251 & 2.507 & 100.000 & & & & & & \\
\hline
\end{tabular}

Extraction Method: Principal Component Analysis.

\subsection{Chi Square Tests}

A different set of questions were asked for further analysis as to whether the respondents belonging to different demography have different opinion on several aspects. For instance the practicing chartered accountants (CAs) may have a different opinion on whether there is a need to have an independent oversight body i.e. NFRA over the auditors vis a vis other respondents 
in the study. As per the results, the chartered accountants do not believe that there is a need of having an independent regulator as they are strongly of the opinion that QRB and PRB can be made more effective to enhance the audit quality. Obviously, they have the fear from independent regulator. The result is corroborated by the chi-square test. The chi-square test results $\left(\chi^{2}(6)>=23.719, p=0.001\right)$ reveals a strong association between the profession of the respondents and their responses (Table 5). The null hypothesis that there is no association between the response and profession of the respondent is rejected at $1 \%$ significance level (Table 5). While academicians and other people think there is a strong need of an independent oversight body, the practicing CAs has completely different opinion.

This is in consonance with the results of Houston and Stefaniak (2013) which reported the apprehension of majority of partners of audit firms on the quality of the PCAOB inspections. The diagonally opposite perception of other groups of the study is not different as found by Robertson and Houston (2010).

Table 5. Cross-tabulation

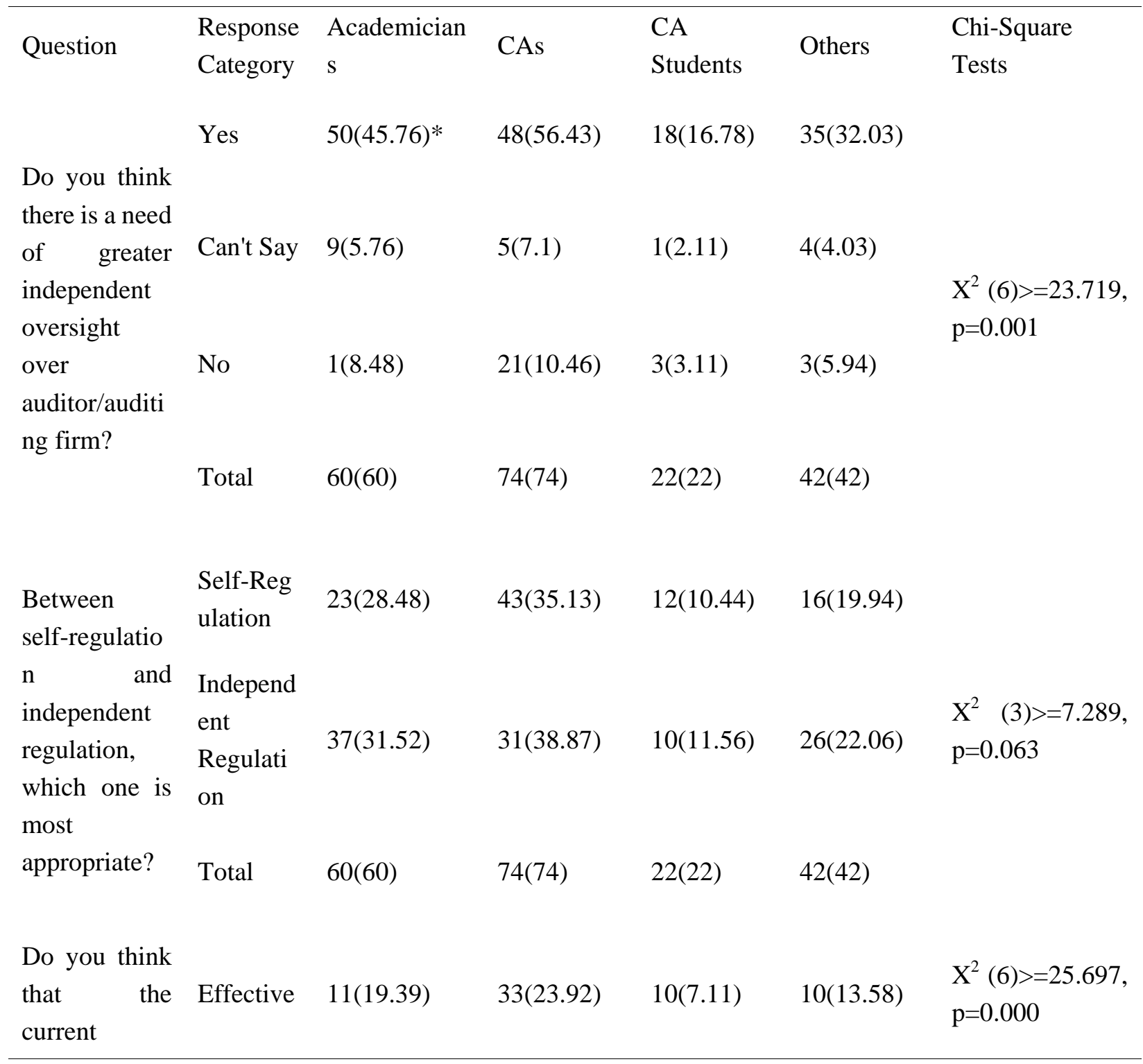


self-regulatio

$n$ by PRB or

Can't Say

$29(21.82)$

$13(26.91)$

7(8.)

23(15.27)

QRB over

auditors is

effective?

$\begin{array}{lllll}\text { Not } & 20(18.79) & 28(23.17) & 5(6.89) & 9(13.15) \\ \text { Effective } & & & & \\ \text { Total } & 60(60) & 74(74) & 22(22) & 42(42)\end{array}$

(Values in parenthesis represent expected count)

When it was asked "Do you think that the current self-regulation by PRB or QRB over auditors is effective?", the results were the same. The null hypothesis that the response is independent of respondents profession is rejected at $1 \%$ significance level by chi-square test $\left(\chi^{2}(6)>=25.697\right.$, $\mathrm{p}=0.000$ ). While academicians have a strong belief that the current self-regulation by PRB or QRB is completely ineffective, the accountants consider it very effective. However, there is a large proportion of practicing accountants as well who consider the ineffectiveness of selfregulation by the current $\mathrm{PRB}$ or QRB.

On the issue of appropriateness between self-regulation and independent regulation the chartered accountants still have the preference for self-regulation. The chi-square test $\left(\chi^{2}\right.$ (3) $>=7.289, p=0.063$ ) is significant at $10 \%$ significance level proving the fact that different profession have different opinion about self-regulation verses independent regulation. Table 5 clearly indicates that while CAs and CA students advocate strongly for self-regulation, academicians and other professionals support the mechanism of independent regulation and the setting up of NFRA.

This study on the expected lines, suggests that differences exist between categories of stakeholders on the perception of self-regulation and independent regulation over the auditors. The chartered accountants and the professional body of chartered accountants (ICAI) are opposed to the formation of NFRA. The ICAI has expressed its disappointment with the formation of NFRA fearing that its role will diminish significantly with a regulator above them. In a letter to the Ministry of Corporate Affairs, Government of India it has registered a protest for exclusion from rules formation of NFRA (Business Standard, 2018). The vehement opposition of public accountants to set up an independent regulator is reflected in their action as well. Northern India CA Federation, an NGO representing CA fraternity of Northern India, filed a petition before the Delhi High Court challenging powers of NFRA and putting unreasonable restriction on the right to freedom of profession of the CAs (Tax Scan, 2018).

The results support the policy intervention of the government based on the opinion that self-regulation has not served the desired purpose and also that the global practice is to have a powerful independent authority to audit the public audit firms.

The point of view of most accountants and auditors is that the Institute of Chartered Accountants of India (ICAI) is a self-regulated professional body with a representation of the government through its nominees in the Disciplinary Committee of ICAI. Furthermore, Peer Review Board and Quality Review Board with 50\% government representation provide 
adequate oversight over the auditors. The members of ICAI strongly feel a need to further strengthened Quality Review Board, which was also recommended by a panel on Corporate Governance constituted by the Securities and Exchange Board of India (SEBI) in its report in October 2017. The SEBI panel also pitched for enhancing the powers of the SEBI to act against auditors and third-party fiduciaries with statutory duties under securities law subject to appropriate safeguards (SEBI, 2017). The ICAI expressed its disapproval citing jurisdictional conflict with the Chartered Accountants Act, 1949 (The Hindu Business Line, 2018).

While opinion in India on self-regulation and independent oversight mechanism is mixed, the global practice is that of independent regulator. One reason for establishing PCAOB was the criticism of peer review by AICPA owing to ineffectiveness stemming from lack of independence (Sulaiman, 2011). An independent body like PCAOB could conduct detailed reviews for extended period of time of selected few audit reports and entities to ensure compliance with the accounting and auditing standards. The inspections of audit firms by the PCAOB are different from the peer reviews in several counts- extent of inspections, timing of inspections and public disclosure of inspection reports with identified deficiencies (Nagy, 2014). Although the PCAOB is created as a private 'non-profit corporation', the Sarbanes-Oxley Act (SOX) has assigned vast powers to the board ranging from enforcing the SOX, the securities laws, regulations of the Securities and Exchange Commission (SEC), and the accounting standards. The funding of PCAOB by the public companies unlike the Canadian Accountability Board (CPAB) wherein accounting firms provide funds (Pritchard and Puri, 2006) is the preferred funding mechanism for independent regulator to minimise the potential conflict of interest. On the lines of the US wherein AICPA reviews still exist after PCAOB, but with greatly reduced scope (Lennox and Pittman, 2010; DeFond, 2010), the setting up of independent regulator in India has not done away with the peer-review by ICAI.

The need of a quasi-regulatory body for supervising audit quality was emphasised in India by the Parliamentary Standing Committee on Finance in 2012. Accordingly, in the Companies Act, 2013, a provision was made for constituting National Financial Reporting Authority (NFRA). While many provisions of the Companies Act, 2013 came into effect from April 1, 2014, the provisions on NFRA were not notified. The trigger to set up NFRA on March 1, 2018 was the PNB fraud of estimated $\$ 3$ billion which questioned the role of the auditors. The shift from peer review to independent regulator under the Companies Act, 2013 is expected to mark an unprecedented change in the regulation and oversight over auditors of public listed companies. The regular inspections by an independent authority would certainly act as a deterrent to those public accountants who are negligent or who make compromises while expressing their audit opinions.

\section{Implications of the Study}

At a general level, results of the study are consistent with the stand taken by the professional body of accountants in India (ICAI) as reported in the media and also a few court cases and representations sent against the formation of NFRA. It is imperative that the accountants recognise the perception of various stakeholders on the need to have a powerful independent regulator over the auditors. The auditors cannot afford a blind eye to the public perception 
accentuated by the indictment of auditors in many recent cases of accounting frauds- Satyam Computers; Neerav Modi; Vijaya Mallya; Infrastructure Leasing \& Finance Services Ltd (IL\&FS); Amrapali group of companies. The professional accountants should take cognizance of the perception of the public and that of the regulators and how this perception is different from their self-interest.

\section{Conclusion}

This study examined the perceptions of accountants and other stakeholders on oversight mechanism over auditors. The study found that all stakeholders including practicing public accountants believe that the present state of auditing is not satisfactory in India. The difference in perception is on the setting up of the independent authority (NFRA) to audit the auditors. While the chartered accountants in India believe that self-regulation over the auditors through the existing Peer Review Board or Quality Review Board may be made more effective as is being done over the years by the ICAI, the other stakeholders do not agree with this state of affairs and they overwhelmingly support independent review of audit service. Results of the study may be considered tentative only as the perception would change definitely once the NFRA starts functioning in the right esteem and inspections of few audit firms are carried out. NFRA has been bestowed with wide powers to regulate the audit profession including the powers to launch suo motu investigations on suspected accounting irregularities. The first case of investigation assigned to the NFRA after its constitution is that of debt-laden Infrastructure Leasing \& Financial Services (IL\&FS) Ltd. NFRA has been asked by the government to look into the role of auditors for lapses and possible collusion with the Board of Directors of IL\&FS to conceal facts.

Since the constitution of NFRA, ICAI seems to have become proactive in disciplining the erring accountants. On October 26, 2018 ICAI suo-motu issued notices to statutory auditors of the Amrapali group companies following the interim report of the forensic auditors appointed by the Supreme Court of India on suspicion of huge diversion of funds of the home buyers of the housing projects of Amrapali (The Hindu Business Line, 2018). In case of the Satyam fraud, ICAI took the disciplinary action of removing the membership of six guilty auditors of PwC who were found to be involved in the fraud. However, the disciplinary proceedings took three years before the action was taken by the ICAI. The ICAI does not have the power to punish the audit firms. It was only in January 2018 that the SEBI imposed a two-year ban on the audit firms (PwC affiliated entities) with respect to the accounting fraud (The Financial Express, 2018).

National Financial Reporting Authority is constituted to audit the auditors by an independent body to enhance the quality of audit service which has been under a severe criticism in the wake of the PNB fraud and other frauds. The wide powers of NFRA and stringent penal provisions should be effective deterrents for the erring auditors. Setting up of NFRA on the lines of PCAOB would certainly fill this gap as is evident that $\mathrm{PwC}$ paid $\$ 7.5$ million as fine to the Securities and Exchange Commission (SEC) of the US and to PCAOB (Reuter, 2011). The composition of the NFRA with representation from all major stakeholders and regulators would to a greater extent reduce multiplicity of regulators whenever audit reports are suspects 
in the event of accounting frauds. After the NFRA begins its reviews of public company audits, the scope of peer reviews would largely be confined to the audits of private companies.

Establishment of independent regulator for enforcing the audit standards and raising the quality of audits should contribute immensely in enhancing trust and credibility of the audit profession. The inclusion of President of ICAI as a member of NFRA should thwart possibility of conflict in the jurisdiction of the ICAI and NFRA.

This study is a preliminary study of perceptions based on 198 respondents belonging to various groups. At this inception stage of constituting independent regulator in India it is immature to offer comment on its effectiveness or otherwise. However, this study provides a preliminary support to the setting up of NFRA. With the working of the NFRA, perceptions of the people including accountants may undergo change depending upon how effectively and independently investigations are carried out by the authority and how effectively it would be able to enhance audit quality.

\section{References}

Alam, P., Hoffman, R. C., \& Heidi, H. M. (2000). Perceptions of the Peer Review Program of the Accounting Profession: Implications for Management. Journal of Managerial Issues, 12(4), 408-442.

Business Standard. (2018). ICAI expresses disappointment with Centre over dismissive stance on NFRA. Retrieved October 19, 2018, from https://www.business-standard.com/article/finance/icai-expresses-disappointment-with-centre -over-dismissive-stance-on-nfra-118101800860_1.html

Daugherty, B., \& Tervo, W. (2010). PCAOB inspections of smaller CPA firms: the perspective of inspected firms. Accounting Horizon, 24, 189-210.

DeFond, M. L. (2010). How should the auditors be audited? Comparing the PCAOB inspections with the AICPA Peer Reviews. Journal of Accounting and Economics, 49, 104-108.

DeFond, M. L., \& Lennox, C. S. (2011). The Effect of SOX on small Auditor exits and audit quality. Journal of Accounting and Economics, 52, 21-40.

Ehlen, C., \& Welker, R. (1996). Procedural Fairness in the Peer and Quality Review Programs. Auditing: A Journal of Practice \& Theory, 15(1), 38-52.

Farrell, J., \& Shabad, H. (2005). The focus of future PCAOB auditor inspections. CPA Journal, 75.

Financial Express. (2018). No intentional wrongdoing in Satyam Fraud, says PW: MCA to examine SEBI order. Retrieved January 12, 2018, from http://epaper.financialexpress.com/1502102/Pune/January-12,-2018\#page/5/2

Gipper, B., Leuz, C., \& Maffett, M. (2015). Public Audit Oversight and Reporting Credibility: Evidence from the PCAOB Inspection Regime. European Corporate Governance Institute 
(ECGI) - Finance Working Paper No. 453/2015, Chicago Booth Research Paper No. 15-40. Retrieved from https://papers.ssrn.com/sol3/papers.cfm?abstract_id=2641211\#\#

Gramling, A. A., Krishnan, J., \& Zhang, Y. (2011). Are PCAOB-identified audit deficiencies associated with change in reporting decisions of triennially inspected audit firms?. Auditing: A Journal of Practice \& Theory, 30(3), 59-81.

Hilary, G., \& Lennox, C. (2005). The credibility of self-regulation: evidence from the accounting profession's peer review program. Journal of Accounting and Economics, 40, 211-229.

Houston, R. W., \& Stefaniak, C. M. (2013). Audit partner perceptions of post-audit review mechanisms: An Examination of Internal Quality Reviews and PCAOB inspections. Accounting Horizons, 27(1), 23-49.

Lennox, C., \& Pittman, J. (2010). Auditing the auditors: Evidence on the recent reforms to the external monitoring of audit firms. Journal of Accounting and Economics, 49, 84-103.

Nagy, A. L. (2014). PCAOB quality control inspection reports and auditor reputation. Auditing: A Journal of Practice \& Theory, 33(3), 87-104.

Pritchard, A. C., \& Puri, P. (2006). The Regulation of Public Auditing in Canada and the United States: Self-Regulation or Government Regulation?. Fraser Institute Digital Publication. Retrieved February 2018, from https://www.fraserinstitute.org/sites/default/files/RegulationofPublicAuditing.pdf

Quality Review Board. (2015). A Report on Audit Quality Review Findings (2012-15). Retrieved from https://www.qrbca.in/wp-content/uploads/2015/07/qrb28179.pdf

Ragothaman, S. (2012). Watching the watchdogs: an examination of the PCAOB quality control inspection reports on triennially inspected audit firms and the AICPA peer review reports. Presented at the 2012 Deloitte Foundation University of Kansas Auditing Symposium.

Retrieved from web.ku.edu/ audsymp/.../Watching\%20the\%20WatchdogsRagothamanApril2012.pdf

Reuter. (2011). PwC in $\$ 25.5$ mln settlement over Satyam audit. Retrieved May 2, 2018, from https://in.reuters.com/article/idINIndia-56713320110502

Robertson, J. C., \& Houston, R. W. (2010). Investors expectations of the improvement in the credibility of audit opinions following PCAOB inspection reports with identified deficiencies. Accounting \& the Public Interest, 10, 36-56.

Russell, J., \& Armitage, J. (2006). Peer review effectiveness: an analysis of potential loopholes within the USA Peer Review program. Managerial Auditing Journal, 21(1), 46-62.

SEBI. (2017). Report of the Committee on Corporate Governance. Retrieved from https://www.sebi.gov.in/reports/reports/oct-2017/report-of-the-committee-on-corporate-gover nance_36177.html 


\section{Ml Macrothink}

International Journal of Accounting and Financial Reporting

ISSN 2162-3082 2018, Vol. 8, No. 4

Sulaiman, N. A. (2011). Audit Quality in Practice: A Study of Perceptions of Auditors, Audit Committee Members and Quality Inspectors. A thesis submitted to the University of Manchester for the degree of Doctor of Philosophy in the Faculty of Humanities. Retrieved from https://www.research.manchester.ac.uk/portal/files/54510755/FULL_TEXT.PDF

Tax Scan. (2018). Delhi HC stays Proceedings by NFRA: Send Notice to Govt on Petition by Chartered Accountants Body. Retrieved October 11, 2018, from http://www.taxscan.in/delhi-hc-stays-proceedings-nfra-send-notice-govt-petition-chartered-ac countants-body/29508/

The Hindu Business Line. (2018). CAs as fiduciaries: ICAI opposes SEBI move. Retrieved September 4 , 2018, from https://www.thehindubusinessline.com/markets/cas-as-market-fiduciaries-icai-opposes-sebimove/article24865919.ece

\section{Copyright Disclaimer}

Copyright for this article is retained by the author(s), with first publication rights granted to the journal.

This is an open-access article distributed under the terms and conditions of the Creative Commons Attribution license (http://creativecommons.org/licenses/by/4.0/) 